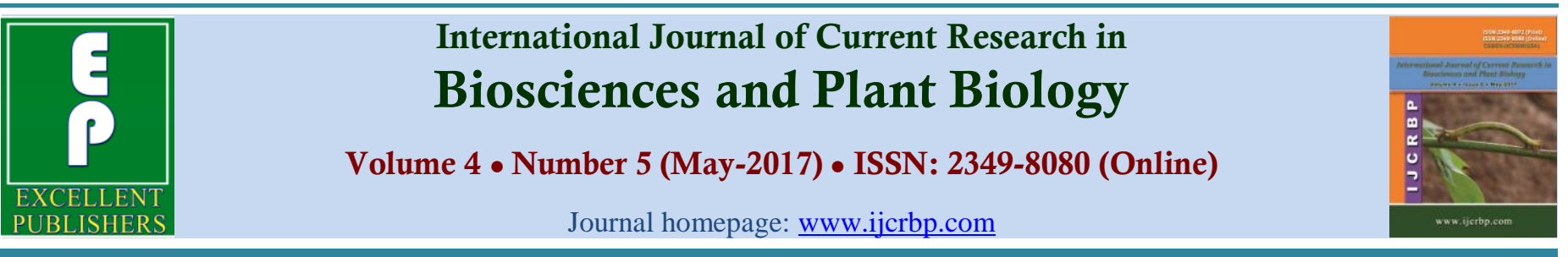

\title{
Phytochemical Screening and Toxicity of Lippia multiflora Moldenke, a Minor Aromatic Leafy Vegetable Consumed in Benin
}

\author{
H. W. Djengue ${ }^{1}$, A. Dansi ${ }^{1,2}$, M.F. Assogba ${ }^{4}$ H. Ahissou ${ }^{3}$, A. Adjatin ${ }^{1,2}$, M. Dansi $^{1,2}$ and D. J. Gbénou $^{4}$ \\ ${ }^{1}$ Laboratory of Biotechnology, Genetic Resources and Plant and Animal Breeding (BIORAVE), Faculty of Sciences and \\ Technology of Dassa, University of Abomey-Calavi, BP 143, Dassa, Benin \\ ${ }^{2}$ Institut de Recherche, de Formation et de Développement sur les Plantes Cultivées, les Animaux d'Elevage et les plantes \\ Médicinales (IRDCAM), 071BP28, Cotonou, Benin \\ ${ }^{3}$ Laboratory of Protein Biochemistry and Enzymology, Faculty of Sciences and Technology (FAST), University of Abomey-Calavi \\ (UAC), P. O. Box 526 Cotonou, Benin \\ ${ }^{4}$ Laboratory of Pharmacognosis and Essential Oil, Faculty of Sciences and Technology, University of Abomey-Calavi, O1 P.O. Box \\ 188, Cotonou, Benin
}

*Corresponding author.

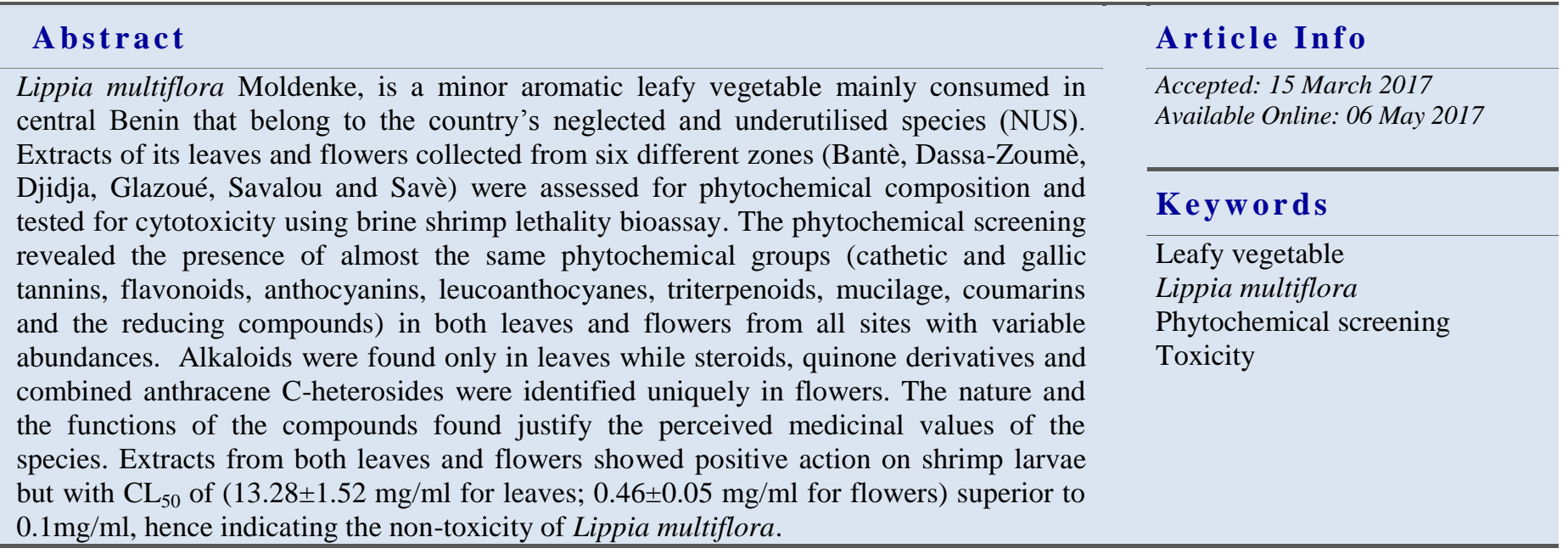

\section{Introduction}

Plants have always been part of the daily life of man and are used for diverse purposes including food, health and clothing (Baba-Aissa, 2000; Gurib-Fakim, 2006). Traditional leafy vegetables are plants whose leaves (including immature green pod and flowers) are socially accepted, used and consumed by the local populations (Dansi et al., 2008). They are rich in fibres, vitamins and minerals (Guarrera and Savo, 2016; Petropoulos et al., 2017). In addition to their high concentration in micronutrients, vegetables provide little dietary energy, making them valuable in energy limited diets. The fibre they contain has been reported to have beneficial effects 
on blood cholesterol and aids in the prevention of large bowel diseases, while in diabetic subjects, they improve glucose tolerance (Odhav et al., 2007; Mensah et al., 2008). Throughout the world and in West Africa in particular, quite a large number of leafy vegetables have long been known and reported to have health protecting properties and uses (Shahriar et al., 2012; Adewale et al., 2013; Ahouansinkpo et al., 2016). In Benin, a total of 187 plant species among with Lippia multiflora Moldenk are consumed as leafy vegetables (Dansi et al., 2008). Lippia multiflora is an aromatic plant, a shrub of the Verbenaceae family whose leaves and flowers are known to have the capacity of treating several illnesses among with are malaria, fever, dysentery, blood pressure, diarrhea, anemia, headaches, constipation, fatigue, diabetes, ulcers and hemorrhoids (Djengue et al., 2017).

Since Lippia multiflora is consumed by Benin local populations, its phytochemical screening need to be carried out and its toxicity examined. The phytochemical screening and the toxicity results will be used to create awareness of their values and, when possible (i.e. if not toxic and trado-medicinal uses supported), popularize their usage in diets as nutraceutical.

The objectives of this study were two folds:

- Carry out a qualitative phytochemical screening of both leaves' and flowers' extracts of different ecotypes of Lippia multiflora.

- Investigate the cytotoxic activity of Lippia multiflora leaves and flowers using brine shrimp assay.

\section{Materials and methods}

\section{Origin and preparation of the samples}

The samples (leaves and flowers) of Lippia multiflora were collected from six districts (Bantè, Dassa Zoumè, Djidja, Glazoué, Savalou and Savè) of central Benin. To prepare the samples, leaves and flowers of Lippia multiflora were washed thoroughly under running tap water followed by sterile distilled water, cut into smaller pieces and dried under shade for 9 days. The dried plant parts were ground using electric blending machine and the powdery samples obtained were sieved using two sieves of $0.2 \mathrm{~mm}$ (mesh size) and stored in air tight sterile containers until needed.

\section{Phytochemical analysis}

Qualitative phytochemical screening of Lippia multiflora was carried out on the powdery samples, after extraction with aqueous solvent, using the standardly employed precipitation and coloration reactions as described by Houghton and Raman (1998) and used by Adjatin et al. (2013), Assogba et al. (2015) and Nounagnon et al. (2016). Major secondary metabolites essayed and the methods used were as follow: Alkaloids (Mayer's test), Quinone derivatives (born-trager reaction), Cathetic tannins (stiasny test), Gallic tannins (ferric chloride test after saturation with sodium acetate), Flavonoids (shinoda test and magnesium powder), Cyanogenic derivatives (picric acid test), Triterpenoids (acetic acid test + mixture of acetic an hydride and sulfuric acid), Steroids (kedde reaction), Saponins (test index foam), Cardiac glycosides (Raymond Marthoud reaction), Anthocyanins (test with hydrochloric acid and ammonia diluted to half), Leucoanthocyanes (shinoda test), Mucilage (test of absolute alcohol), Reducing compounds (test with fehling's solution), Coumarins (test with ether and ammonia), Free anthracene derivatives (test with chloroform and ammonia), Combined anthracene derivatives (test with chloroform and ammonia).

\section{Brine shrimp lethality assay}

The cytotoxic activity of the extracts of leaves and flowers of Lippia multiflora was evaluated using Brine shrimp lethality bioassay following Agbaire et al. (2013) and Ahouansinkpo et al. (2016). Brine shrimp (Artemia salina Leach) also known as sea monkey are marine invertebrates of about $1 \mathrm{~mm}$ in size. The test is based on the survival of shrimp larvae in sea water in the presence of the test solution. Its interest lies in understanding the possible side effects that would result from consumption of leaves and flowers of Lippia multiflora on the body. A solution was prepared by moderate heating for 20 minutes, the mixture of $1 \mathrm{~g}$ of powdered leaves and flowers of Lippia multiflora in $20 \mathrm{ml}$ of distilled water following Adjatin et al. (2013); Agbankpé et al. (2015). The concentration of 50 $\mathrm{mg} / \mathrm{ml}$ was obtained and a range of ten successive dilutions $(49 \mu \mathrm{g} / \mathrm{ml}, 98 \mu \mathrm{g} / \mathrm{ml}, 195 \mu \mathrm{g} / \mathrm{ml}, 391 \mu \mathrm{g} / \mathrm{ml}$, $781 \mu \mathrm{g} / \mathrm{ml}, 1582 \mu \mathrm{g} / \mathrm{ml}, 3125 \mu \mathrm{g} / \mathrm{ml}, 6250 \mu \mathrm{g} / \mathrm{ml}, 12500$ $\mu \mathrm{g} / \mathrm{ml}$ and $25000 \mu \mathrm{g} / \mathrm{ml}$ ) were made with sea water from decoction. Eggs of $A$. salina were grown in an Erlenmeyer containing sea water taken from the 
Atlantic Ocean and filtered before use. The mixture (eggs and sea water) was left under stirring for 48 hours. Meanwhile, the eggs were hatched to give birth to young larvae (nauplii). Using a pipette, a colony of 16 live larvae was placed in contact with the series of solutions of graded concentrations of decoction of Lippia multiflora. These solutions and the controls containing no extract of Lippia were left stirring and read after 24 hours of incubation. The total death and percentage of mortality at each dose level and control were determined. To assess the degree of toxicity of the different samples, the LC50 and toxicity corresponding table (Table 1) was used following Mousseux (1995) and Adjatin et al. (2013).

\section{Statistical analysis}

For each extract or sample, the lethal concentration that causes 50\% death (LC50) was calculated at 95\% confidence interval by linear regression analysis and also by using the Probit analysis method following Adjatin et al. (2013), Ahouansinkpo et al. (2016). A regression line equation was derived for each extract with the mortality data obtained and used to calculate the LC50 value. The detailed mathematical steps used to derive the regression line equation are reported in the literature (Dougnon et al., 2013; Adjatin et al., 2013; Ahouansinkpo et al., 2016).

Table 1. Correspondence between $\mathrm{LC}_{50}$ and toxicity.

\begin{tabular}{ll}
\hline $\mathbf{L C}_{50}$ & Toxicity \\
\hline $\mathrm{LC}_{50} \geq 0.1 \mathrm{mg} / \mathrm{ml}$ & - \\
$0.1 \mathrm{mg} / \mathrm{ml}>\mathrm{LC}_{50} \geq 0.050 \mathrm{mg} / \mathrm{ml}$ & + \\
$0.050 \mathrm{mg} / \mathrm{ml}>\mathrm{LC}_{50} \geq 0.01 \mathrm{mg} / \mathrm{ml}$ & ++ \\
$\mathrm{LC}_{50}<0.01 \mathrm{mg} / \mathrm{ml}$ & +++ \\
\hline
\end{tabular}

NB: No toxic; +: Low toxicity; ++: Moderate toxicity; +++: High toxicity

\section{Results and discussion}

\section{Phytochemical screening}

The phytochemical screening of the extracts of leaves and flowers of Lippia multiflora collected in the six different districts highlighted the presence of several phytochemical compounds that are well-known to have interesting biologic properties (Table 2). These were alkaloids, cathetic and gallic tannins, flavonoids, anthocyanins, leucoanthocyanes, triterpenoids, mucilage, coumarins and the reducing compounds in the extracts of leaves of the six zones and cathetic and gallic tannins, flavonoids, anthocyanins, leucoanthocyanes, triterpenoids, steroids, mucilage, coumarins, the reducing compounds and the combined anthracene Cheterosides in the extracts of the flowers of the six zones. The same phytochemical compounds were observed in the different extracts of the leaves in one hand and in the different extracts of the flowers in the other hand. A variation is noted between districts in terms of the relative concentrations (Table 2). For instance, the triterpenoids is more concentrated in the extracts of the samples from Savalou and Bantè than in the one of the other zones. Similar results were reported by Lébri et al. (2015) in Ivory Coast for Abrus precatorius and by Agbankpé et al. (2015) in Benin for Vernonia amygdalina. However, quantitative analysis is still required for confirmation following Medoatinsa et al. (2016) and Ramdane et al. (2017). The difference of relative concentration of these phytochemical elements observed, if confirmed, could be due to climate, soil, physiological stages of the plant growth or the genotypes of the plants sampled.

A variation is also observed between the qualitative phytochemical composition of the two organs (leaves and flowers) of Lippia multiflora (Table 2). The alkaloids are present in the extracts of leaves but absent in those of flowers while the steroids and the combined anthracene C-heterosides are presents in the extracts of flowers but absent in those of leaves. Such differences of phytochemical composition was reported by Dohou et al. (2003) on various organs (Leaves, flowers, roots, peel and fruits) of Thymelaea lythroides, Dougnon et al. (2012) on fruits and leaves of Solanum macrocarpum and Tsiba et al. (2010) in Congo on the essential oils of leaves, flowers, roots, and stems of Lippia multiflora itself.

Lippia multiflora has various medicinal virtues that can be explained by its phytochemical composition. The alkaloids for instance have antibiotic, anti-parasite, antihelminthic, anesthetics, anti-tumorous or anti-cancer, antidiabetic, anti-malaria and analgesics properties (Anandhi and Revathi, 2013; Ahouansikpo et al., 2016). Their presence in the leaves of Lippia multiflora justifies their use in the treatment of malaria and of infections by the populations. The anthracene C-heterosides has a laxative or purgative action (Adjatin et al., 2013) and this confirms the use of flowers as laxative by the local communities. Natural coumarins (Aromatic phytochemical compounds with a vanilla like flavour) 
have recently drawn much attention due to its broad pharmacological activities (Bruneton, 2009). Many coumarins and their derivatives exert anti-fungal, anticoagulant, anti-tumour, anti-malaria, anti-viral, antiinflammatory, diuretic, analgesic, anti-oedema, antioxidant and anti-microbial effects and have enzyme inhibition properties. Coumarins increase the blood flow in the veins and decreases capillary permeability. Lippia multiflora is aromatic (Djengue et al., 2017). The smell of this vegetable and its medicinal properties may be also linked to the presence of coumarins. The antioxidant property of tannins, flavonoids and coumarins make them capable of protection against free radicals which are responsible of more than 200 human diseases including cardiovascular disease, cancer, arthritis, sight disorder and ageing (Oszmianski et al, 2007; Ouali et al., 2007; Mir et al., 2012; Adjatin et al.,
2013). Steroids are known for their analgesic, antimicrobial, anti-inflammatory and cardiotonic properties (Hossain et al., 2013; Ekissi et al., 2014). They regulate carbohydrate and protein metabolism, increase muscles and bone synthesis and are also associated with hormonal control in women (Hossain et al., 2013). Mucilage (soluble fibres) also has several medicinal properties (Dougnon et al., 2012; Adjatin et al., 2013; Agbaire et al., 2013; Simons, 2013). It is anti-cholesterol (aid to lower cholesterol in the blood), anti-constipation (helps to prevent the appearance of intestinal decomposition), anti-cancer, anti-diabetic agents and stomachic (has ability to protect internal mucous membranes). The other compounds also have interesting medicinal value (Adjatin et al., 2013; Vijayameena et al., 2013; Agbankpé et al., 2015).

Table 2. Qualitative assessment of phytochemical compounds in the leaves and flower of Lippia multiflora from six districts.

\begin{tabular}{|c|c|c|c|c|c|c|c|c|c|c|c|c|}
\hline \multirow[t]{2}{*}{ Phytochemical compounds } & \multicolumn{2}{|c|}{ BANTE } & \multicolumn{2}{|c|}{ DASSA } & \multicolumn{2}{|c|}{ DJIDJA } & \multicolumn{2}{|c|}{ GLAZOUE } & \multicolumn{2}{|c|}{ SAVALOU } & \multicolumn{2}{|c|}{ SAVE } \\
\hline & $\mathbf{L}$ & $\mathbf{F}$ & $\mathbf{L}$ & $\mathbf{F}$ & $\mathbf{L}$ & $\mathbf{F}$ & $\mathbf{L}$ & $\mathbf{F}$ & $\mathbf{L}$ & $\mathbf{F}$ & $\mathbf{L}$ & $\mathbf{F}$ \\
\hline Alkaloids & \pm & - & \pm & - & \pm & - & \pm & - & \pm & - & \pm & - \\
\hline \multicolumn{13}{|l|}{ Poly-phenolic compounds } \\
\hline gallic tannins & + & + & + & + & + & + & + & + & + & + & + & + \\
\hline Cathetic tanins & + & + & + & + & + & + & + & + & + & + & + & + \\
\hline Flavonoids & + & + & + & + & + & + & + & + & + & + & + & + \\
\hline Quinone derivatives & - & \pm & - & \pm & - & \pm & - & \pm & - & \pm & - & \pm \\
\hline Saponins & - & - & - & - & - & - & - & - & - & - & - & - \\
\hline Triterpenoids & + & + & + & + & + & + & \pm & \pm & + & + & + & + \\
\hline Steroids & - & + & - & + & - & + & - & + & - & + & - & + \\
\hline Cyanogenic derivatives & - & - & - & - & - & - & - & - & - & - & - & - \\
\hline \multicolumn{13}{|l|}{ Anthracene derivatives } \\
\hline Free anthracene derivatives & - & - & - & - & - & - & - & - & - & - & - & - \\
\hline $\begin{array}{l}\text { Combined anthracene O- } \\
\text { heterosides }\end{array}$ & - & - & - & - & - & - & - & - & - & - & - & - \\
\hline $\begin{array}{l}\text { Combined anthracene C- } \\
\text { heterosides }\end{array}$ & - & \pm & - & \pm & - & \pm & - & \pm & - & \pm & - & \pm \\
\hline Glycosides cardiotonic & - & - & - & - & - & - & - & - & - & - & - & - \\
\hline
\end{tabular}

+: Presence; +: Trace; -: Absence; L: Leaves; F: Flowers.

\section{Toxicity degree of Lippia multiflora}

The Lippia multiflora leaves and flowers extracts tested showed lethality on the shrimp's larvae indicating that the samples are biologically active. A variability of the lethality rate was observed with the different concentrations, the zones and the organs used (Table 3;
Table 4). For the leaves, the highest lethality rate was observed with the samples from Djidja $(15.18 \mathrm{mg} / \mathrm{ml})$ and the lowest with the samples from Bantè (11.52 $\mathrm{mg} / \mathrm{ml}$ ). For the flowers' extracts, the highest LC50 value was obtained with the samples of Djidja $(0.55$ $\mathrm{mg} / \mathrm{ml})$ and the lowest with the samples of Bantè $(0.42$ $\mathrm{mg} / \mathrm{ml}$ ). Considering the table of correspondence 
established by Mousseux (1995), the $\mathrm{LC}_{50}$ of the different organs and of the different zones are superior to $0.1 \mathrm{mg} / \mathrm{ml}$ (Table 1) meaning that the leaves and the flowers are not toxic. These results are similar to those reported by Kosgei et al., (2014) on Lippia kituiensis.
Our results indicated that Lippia multiflora is among the non-toxic Benin local leafy vegetables like $C$. crepidioides and $C$. rubens (Adjatin et al., 2013), Launaea taraxacifolia (Koukoui et al., 2015), and Cleome gynandra (Ahouansikpo et al., 2016).

Table 3. Values of $\mathrm{LC}_{50}$ of the extracts of leaves of Lippia multiflora from different zones.

\begin{tabular}{llll}
\hline Extract of leaves of $\boldsymbol{L}$. multiflora & Polynomial regressions & $\mathbf{R}^{\mathbf{2}}$ & $\mathbf{L C}_{\mathbf{5 0}}(\mathbf{m g} / \mathbf{m l})$ \\
\hline Bantè & $\mathrm{y}=-0.013 \mathrm{x}^{2}+0.832 \mathrm{x}+0.138$ & 0.959 & 11.52 \\
Dassa & $\mathrm{y}=-0.010 \mathrm{x}^{2}+0.763 \mathrm{x}+0.144$ & 0.968 & 12.26 \\
Djidja & $\mathrm{y}=-0.007 \mathrm{x}^{2}+0.633 \mathrm{x}-0.002$ & 0.982 & 15.18 \\
Glazoué & $\mathrm{y}=-0.003 \mathrm{x}^{2}+0.640 \mathrm{x}+0.097$ & 0.985 & 13.16 \\
Savalou & $\mathrm{y}=-0.007 \mathrm{x}^{2}+0.647 \mathrm{x}-0.171$ & 0.994 & 15.09 \\
Savè & $\mathrm{y}=-0.006 \mathrm{x}^{2}+0.709 \mathrm{x}+0.090$ & 0.982 & 12.47 \\
\hline Means & & $\mathbf{1 3 . 2 8}$ \\
Standard Deviation & & 1.52 \\
Coefficient of variation $(\%)$ & & $11.44 \%$ \\
\hline
\end{tabular}

Table 4. Values of LC50 of the extracts of flowers of Lippia multiflora from different zones.

\begin{tabular}{llll}
\hline Extracts of flowers of $\boldsymbol{L}$. multiflora & Logarithmic regressions & $\mathbf{R}^{\mathbf{2}}$ & $\mathbf{L C}_{\mathbf{5 0}}(\mathbf{m g} / \mathbf{m l})$ \\
\hline Bantè & $\mathrm{y}=2.902 \ln (\mathrm{x})+10.51$ & 0.803 & 0.42 \\
Dassa & $\mathrm{y}=2.981 \ln (\mathrm{x})+10.20$ & 0.842 & 0.48 \\
Djidja & $\mathrm{y}=3.016 \ln (\mathrm{x})+9.799$ & 0.877 & 0.55 \\
Glazoué & $\mathrm{y}=2.972 \ln (\mathrm{x})+10.50$ & 0.782 & 0.43 \\
Savalou & $\mathrm{y}=2.867 \ln (\mathrm{x})+10.31$ & 0.843 & 0.45 \\
Savè & $\mathrm{y}=2.964 \ln (\mathrm{x})+10.40$ & 0.802 & 0.44 \\
\hline Means & & $\mathbf{0 . 4 6}$ & 0.05 \\
Standard Deviation & & 10.86 \\
Coefficient of variation $(\%)$ & & \\
\hline
\end{tabular}
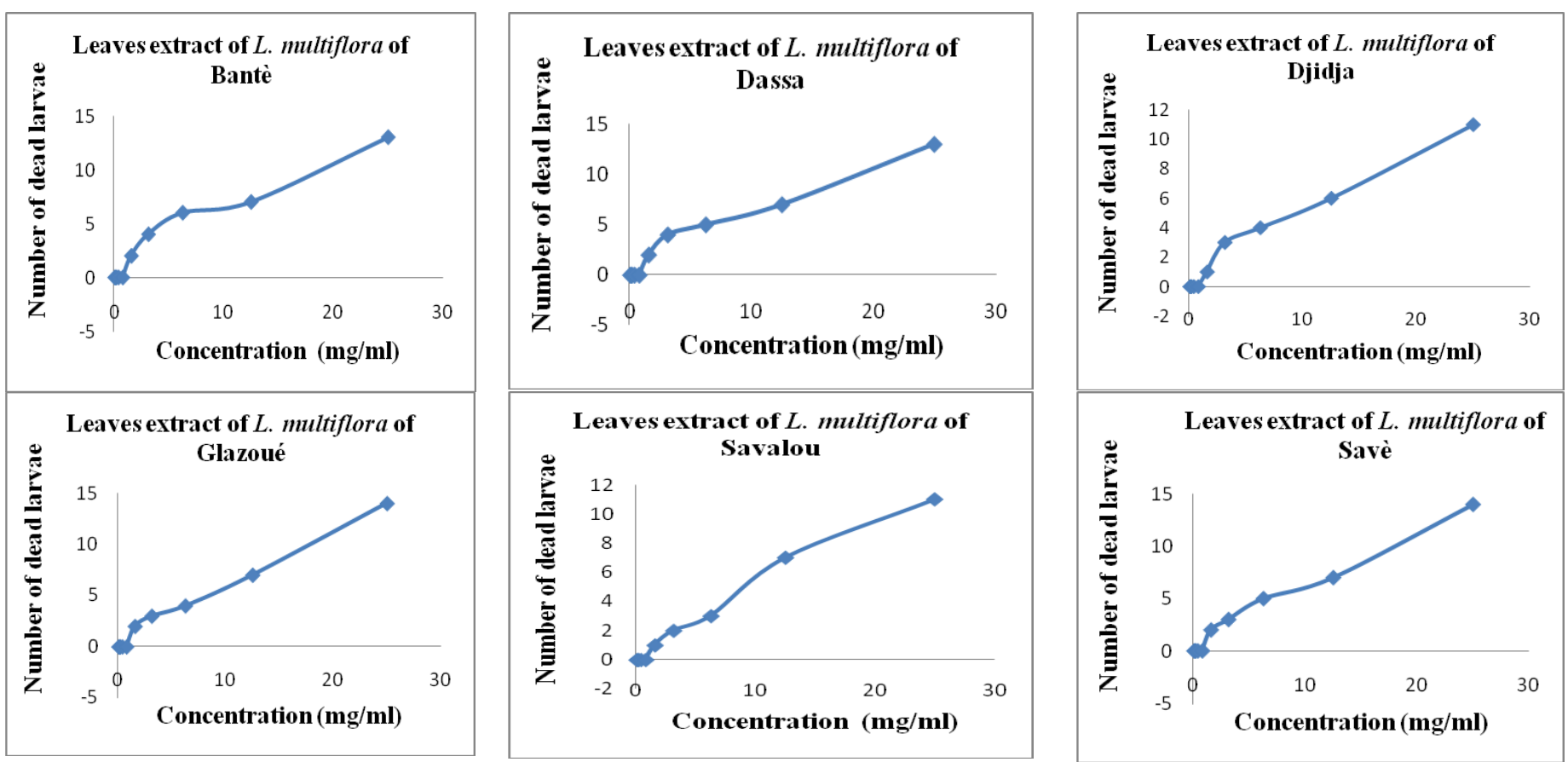

Fig. 1: Toxicity curve of the extracts of Lippia multiflora leaves of six zones against shrimp larvae. 

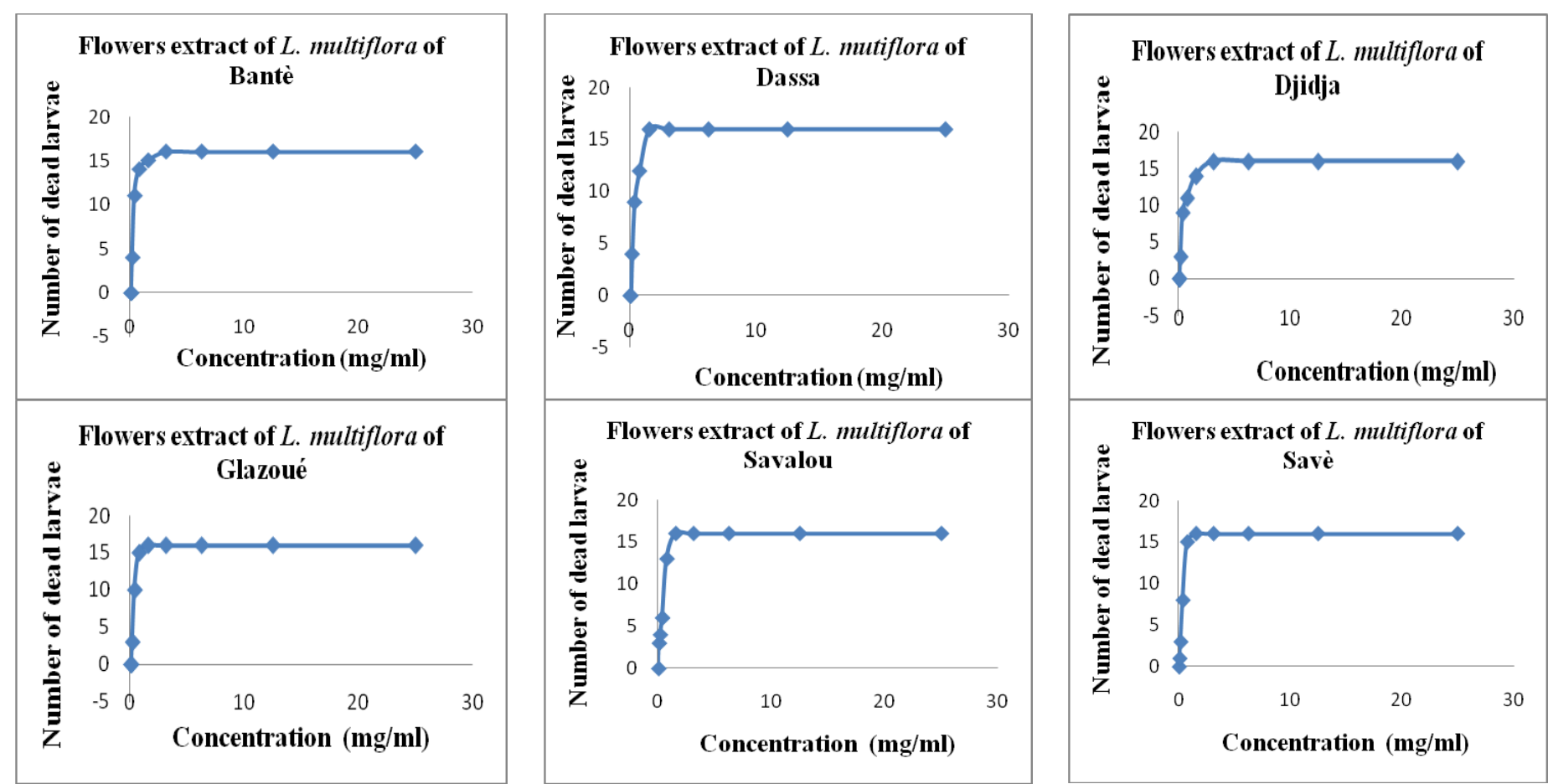

Fig. 2: Toxicity curve of the extracts of Lippia multiflora flowers of six zones against shrimp larvae.

\section{Conclusion}

This study focused on the phytochemical screening and larval toxicity of the leaves and flowers of Lippia multiflora. It confirms the presence of some phytochemical compounds that are known to have medicinal properties justifying the use of the plant in traditional medicine. Furthermore, the non-toxicity of these vegetable will allow to promote their use in food for nutritional purposes and in traditional medicine for the therapeutic properties. However, the use of sophisticated and more advanced methods for the phytochemical screening and the cytotoxicity tests would be of high important to improve this study.

\section{Conflict of interest statement}

Authors declare that they have no conflict of interest.

\section{References}

Adjatin, A., Dansi, A., Badoussi, E., Loko, Y. L., Dansi, M., Azokpota, P., Gbaguidi, F., Ahissou, H., Akoègninou, A., Akpagana, K., Sanni, A., 2013. Phytochemical screening and toxicity studies of Crassocephalum rubens (Juss. ex Jacq.) S. Moore and Crassocephalum crepidioides (Benth.) S. Moore consumed as vegetable in Benin. Int. J. Curr.
Microbiol. App. Sci. 2(8), 1-13.

Agbaire,P.O., Emudainohwo, J.O.T., Peretiemo-Clarke, B. O., 2013. Phytochemical screening and toxicity studies on the leaves of Manniophyton fulvum. Int. J. Plant Anim. Environ. Sci. 3(1), 1-6.

Agbankpé, A. J., Bankolé, S. H., Assogba, F., Dougnon, T. V., Yèhouénou, B., Gbénou, J., Baba-Moussa, L., 2015. Phytochemical screening and cytotoxic analysis of three local vegetables used in the treatment of bacterial diarrhoea in Southern Benin (West Africa): A comparative study. Brit. Biotechnol. J. 9(4), 1-13.

Ahouansinkpo, E., Atanasso, J., Dansi, A., Adjatin, A., Orobiyi, A., Sanni, A., 2016. Ethnobotany, phytochemical screening and toxicity risk of Cleome gynandra and Cleome viscosa, two traditional leafy vegetables consumed in Benin. Int. J. Curr. Microbiol. App. Sci. 5(2), 813-829.

Akbar Adewale, A., Ayoade, A. A., Alani, E. A., 2013. Determination of vitamins in five selected West African green leafy vegetables. J. Amer. Sci. 9(2), 40-43.

Anandhi, D., Revathi, K., 2013. Phytochemical analysis of Caesalpinia coriaria (Jacq.) Wild. Int. J. Biosci. Res. 2(1), 1-7.

Assogba, F. M., Aderomou, C., Agbodjogbe, W., Moudachirou, M., Gbenou, J. D., 2015. Evaluation of diuretic properties from Elaeis guineensis Jacq. 
(Arecaceae) leaves aqueous extract in Wistar rat. J. Chem. Pharmaceut. Res. 7(3), 2457-2462.

Baba-Aissa, F., 2000. Encyclopédie des plantes utiles, flore d'Algérie et du Maghreb, substances végétales d'Afrique, d'Orient et d'Occident. Ed. EDAS, Algérie. 368p.

Bruneton, J., 1999. Parmacognosie-Phytochimie-Plantes Médicinales. 3rd Édn. Éditions Tec \& Doc et Médicales Internationales, Cachan, Paris. 1120p.

Dansi, A., Adjatin, A., Adoukonou-Sagbadja, H., Faladé, V., Yedomonhan, H., Odou, D., Dossou, B., 2008. Traditional leafy vegetables and their use in the Benin Republic. Genet. Resour. Crop Evol. 55, 1239-1256.

Djengue, H. W., Dansi, A., Adjatin, A., DossouAminon, I., Dansi, M., Sanni, A., 2017. Ethnobotanical investigation of Lippia multiflora Moldenke, a local aromatic leafy vegetable under domestication in Benin. Int. J. Curr. Res. Biosci. Plant Biol. 4(5), 44-51.

Dohou N., Yamni K, Tahrouch S., IdrissiHassani L.M, Badoc A, Gmira N. 2003. Screening phytochimique d'uneendémiqueibéro-marocaine,

thymelaealythroides. Bull. Soc. Pharm. Bordeaux, 2003, 142, 61-78.

Dougnon, T.V., Bankolé, H.S., Edorh, A.P., Dougnon, T.J., Klotoé, J.R., Loko, F., Boko, M., 2013. Cytotoxicity of leaves and fruits of Solanum macrocarpon Linn (Solanaceae) against shrimp larvae (Artemia salina Leach). Res. J. Recent Sci. 2(5), 6-9.

Dougnon, T.V., Bankolé, H.S., Johnson, R.S., Klotoé, J.R., Fernand, G.D., Assogba, G.F., 2012. Phytochemical screening, nutritional and toxicological analyses of leaves and fruits of Solanum macrocarpon Linn. (Solanaceae) in Cotonou (Benin). Food Nutr. Sci. 3, 1595-1603.

Ekissi, A. C., Konan, A. G., Yao-Kouame, A., Bonfoh, B., Kati-Coulibaly, S., 2014. Sensory evaluation of green tea from Lippia multiflora Moldenke leaves. Eur. Scientific J. 10(3), 536-545.

Guarrera, P.M., Savo, V., 2016. Wild food plants used in traditional vegetable mixtures in Italy. J. Ethnopharmacol. 185, 202-234.

Gurib-Fakim, A., 2006. Medicinal plants: Traditions of yesterday and drugs of tomorrow. Mol. Aspects Med. 27(1), 1-93.

Hossain, H., Jahan, I A., Howlader, S..I., Dey, S.K., Hira, A., Ahmed, A., 2013. Phytochemical screening and anti-nociceptive properties of the ethanolic leaf extract of Trema cannabina Lour. A.
Adv. Pharmaceut. Bull. 3(1), 103-108.

Houghton, P.J., Raman, A., 1998. Laboratory Handbook for the Fractionation of Natural Extracts. Chapman and Hall, New York.

Kosgei, C.J., Matasyoh, J.C., Mwendia, C.M., Kariuki, S.T., Guliye, A.Y., 2014. Chemical composition and larvicidal activity of essential oil of Lippia kituiensis against larvae of Rhipicephalus appendiculatus. Int. J. Biol. Chem. Sci. 8(4), 1938-1947.

Koukoui, O., Agbangnan, P., Boucherie, S., Yovo, M., Nusse, O., Combettes, L., Sohounhloué, D., 2015. Phytochemical study and evaluation of cytotoxicity, antioxidant and hypolipidemic properties of Launaea taraxacifolia leaves extracts on cell lines HepG2 and PLB985. Amer. J. Plant Sci. 6, 17681779.

Lébri, M., Bahi, C., Fofie, N.B.Y., Gnahoue, G., Lagou, S. M., Achibat, H., Yapi, A., Zirihi, G.N., Coulibaly, A., Hafid, A., Khouili, M., 2015. Analyse phytochimique et évaluation de la toxicité aiguë par voie orale chez des rats de l'extrait total aqueux des feuilles de Abrus precatorius Linn. (Fabaceae). Int. J. Biol. Chem. Sci. 9(3), 1470-1476.

Medoatinsa, S.E., Agbangnan, C.P.D., Bogninou, G.S.R., Ahissou, H., Bothon F.T.D., Wottoalentin, V., Félicien, A., Sohounhloue, D., 2016. Phytochemical profile and antioxidant potential of 12 antimalarial recipes used in lacustrine sreas in Benin. Int. J. Pharmaceut. Sci. Invent. 5(7), 16-21.

Mensah J.K., Okoli R.I., Ohaju-Obodo J.O., Eifidiyi K. 2008. Phytochemical, nutritional and medicinal properties of some leafy vegetables consumed by Edo people of Nigeria. Afr. J. Biotechnol., 7: 2305- 2308.

Mir, M.A., Sawhney, S. S., Kumar, S., 2012. Comparative studyupon the antioxidant potential of Saraca indica and Pterospermum acerifolium. J. Chem. Pharm. Res. 4, 4716-4720.

Mousseux, M., 1995. Test de toxicité sur les larves de Artemia salina et d'entretien d'un élevage de balanes, Rapport de stage de deuxième année. DEUST Aquaculture; Centre Universitaire de Nouvelle-Calédonie, France.

Nounagnon, S. M., N'tcha, C., Sina, H., Noumavo, A. P., Dah-Nouvlessounon, D., Assogba, M. F., Gbénou, D. J., Baba-Moussa, L., 2016. Antimicrobial activities of Combretum micranthum extracts on Staphylococcus aureus strains isolated from skin infections and some reference strains. Asian J. Plant Sci. Res. 6(4), 40-47.

Odhav, B., Beekrum, S., Akula, U., Baijnath, H., 2007. 
Preliminary assessment of nutritional value of traditional leafy vegetables in KwaZulu-Natal, South Africa. J. Food Composit. Anal. 20, 361-448.

Oszmianski, J., Wojdylo, A., Lamer-Zarawska, E., Swiader, K., 2007. Antioxidant tannins from Rosaceae plant roots. Food Chem. 100(2), 579-583.

Ouali, K., Trea, F., Toumi, L., Bairi, A., Maurel, D., Guellati, M.A., 2007. L'hespéridine, un antioxydant flavonoïde qui diminue le stress oxydatif et prévient les malformations foetales au cours du diabète gestationnel expérimental. Phytothér. 5(4), 204-209.

Petropoulos, S.A., Levizou, E., Ntatsi, G., Fernandes, Â., Petrotos, K., Akoumianakis, K., Barros, L., Ferreira, I.C., 2017. Salinity effect on nutritional value, chemical composition and bioactive compounds content of Cichorium spinosum L. Food Chem. 214, 129-136.

Ramdane, F., Essid, R., Mkadmini, K., Hammami, M., Fares, N., Hadj, M.M., El Ouassis, D., Tabbene, O., Limam, F., 2017. Phytochemical composition and biological activities of Asteriscus graveolens
(Forssk) extracts. Process Biochem. 56, 186-192.

Shahriar, M., Hossain, Md. I., Bahar, A.N. Md., Akhter, S., Haque Md A., Bhuiyan, M. A., 2012. Preliminary phytochemical screening, in-vitro antioxidant and cytotoxic activity of five different extracts of Moringa oleifera leaf. J. Appl. Pharmaceut. Sci. 2(5), 65-68.

Simons, A., 2013. The Healing Power of Plants: Medical Plants from Abuta and Acerola to Yohimbe and Yucca: a Practical Selection. Maya Media Verlag.

Tsiba, G., Célestine, N. L., Yaya, M., Jean-Maurille, O., Antoine, A. A., Jean-Claude, C., Gilles, F., 2010. Variation in the chemical composition of the essential oils of different organs of domesticated Lippia multiflora Moldenke. Afr. J. Biotechnol. 9(41), 7009-7013.

Vijayameena, C., Subhashini, G., Loganayagi, M., Ramesh, B., 2013. Phytochemical screening and assessment of antibacterial activity for the bioactive compounds in Annona muricata. Int. Curr. Microbiol. App. Sci, 2 (1), 1-8.

\section{How to cite this article:}

Djengue, H. W., Dansi A., Assogba, M. F., Ahissou, H., Adjatin, A., Dansi, M., Gbénou, D.J., 2017. Phytochemical screening and toxicity of Lippia multiflora Moldenke, a minor aromatic leafy vegetable consumed in Benin. Int. J. Curr. Res. Biosci. Plant Biol. 4(5), 77-84. doi: https://doi.org/10.20546/ijcrbp.2017.405.011 